\title{
myo-Inositol and sorbitol in erythrocytes from diabetic patients before and after sorbinil treatment
}

\author{
C.Popp-Snijders ${ }^{1}$, M.Z. Lomecky-Janousek ${ }^{1}$, J.A. Schouten ${ }^{2}$ and E. A. van der Veen ${ }^{1}$ \\ Departments of ${ }^{1}$ Endocrinology and ${ }^{2}$ Internal Medicine, Free University Hospital, Amsterdam, The Netherlands
}

\begin{abstract}
Summary. Erythrocytes from diabetic patients before and after treatment with the aldose reductase inhibitor, sorbinil, were analyzed by a capillary gas chromatographic method for sorbitol and myo-inositol. The mean erythrocyte sorbitol level in the diabetic patients was significantly higher than in the control subjects $(13.1 \pm 0.9$ and $5.2 \pm 0.3 \mathrm{nmol} / \mathrm{ml}$ erythrocytes, respectively, mean \pm SEM, $p<0.001$ ). The mean erythrocyte myo-inositol level in diabetic patients was not different from that in control subjects ( $43.2 \pm 2.9$ and $40.5 \pm 1.9 \mathrm{nmol} /$
\end{abstract}

$\mathrm{ml}$ erythrocytes, respectively). Sorbinil treatment reduced the elevated sorbitol levels in the diabetic patients to normal or slightly below normal, but did not affect the erythrocyte myoinositol concentration. It is concluded that the erythrocyte is not a suitable model to monitor a possible effect of sorbinil on myo-inositol concentration in less accessible tissues.

Key words: myo-inositol, sorbitol, erythrocytes, diabetes, aldose reductase, sorbinil.
The induction of experimental diabetes leads to a decrease in nerve conduction velocity, which is associated with increased levels of glucose, sorbitol and fructose, and decreased levels of myo-inositol in the nerve tissue [1-3]. Insulin treatment can correct these metabolic abnormalities and will attenuate nerve conduction velocity defects. A restoration of nerve conduction velocity can also be achieved either by reducing nerve sorbitol concentrations to normal by treatment with aldose reductase inhibitors, or by restoring to normal the nerve myo-inositol concentration by an increased dietary intake of myo-inositol [3-5].

Recently a relationship between increased sorbitol concentration and decreased myo-inositol concentration in peripheral nerves of diabetic rats has been demonstrated [6, 7]. Treatment of streptozotocin-diabetic rats with aldose reductase inhibitors, which restore nerve sorbitol concentrations to normal, also corrected the reduced myo-inositol concentration in nerve.

In diabetic patients evidence of metabolic abnormalities in the nerve tissue has been obtained from measurement of polyols in cerebrospinal fluid $[8,9]$ and sciatic nerves obtained post-mortem [10]. To study the sorbitol pathway activity in vivo, erythrocytes can be used as a model for less accessible tissues, and the effects of aldose reductase inhibitors have been monitored by measuring erythrocyte sorbitol concentrations $[11,12]$.

The aim of the present study was to investigate the effect of the aldose reductase inhibitor, sorbinil, on sorbitol and myo-Inositol concentrations in erythro- cytes. myo-Inositol and sorbitol concentrations were measured in erythrocytes from Type 1 (insulin-dependent) and Type 2 (non-insulin-dependent) diabetic patients before and after sorbinil treatment, using a specific mass-spectrometric controlled capillary gas chromatographic assay.

\section{Subjects and methods}

\section{Subjects}

Twenty-eight Type 1 and Type 2 diabetic patients participated, after giving informed consent, in a double-blind parallel-group placebocontrolled study. Approval was given by the Ethical Committee of the Free University Hospital, Amsterdam. Clinical details of the patients at the start of the study are given in Table 1. A 4-week placebo period was followed by a 12-week sorbinil or placebo period and subsequently by a 4-week placebo period. The sorbinil dose was $200 \mathrm{mg}$ daily. After 4, 8, 12, 16 and 20 weeks (periods 1, 2, 3, 4 and 5, respectively) blood was sampled between 13.00 and $16.00 \mathrm{~h}$ for the determination of erythrocyte myo-inositol (24 patients), erythrocyte sorbitol (28 patients), glycosylated haemoglobin $\left(\mathrm{HbA}_{1}\right)$ and plasma sorbinil. Reference values were obtained from heparinized blood samples of 30 non-diabetic healthy volunteers after an overnight fast. This control group consisted of 12 female and 18 male subjects, the mean \pm SD age was $35.2 \pm 9.5$ years (range $20-62$ years).

\section{Methods}

Erythrocyte myo-inositol and sorbitol were determined by a capillary gas chromatographic method as described previously [13]. The identities of myo-inositol and sorbitol and their single elution from the capillary column were confirmed by mass-spectrometry. Sorbitol and myo-inositol values are expressed as $\mathrm{nmol} / \mathrm{ml}$ packed erythrocytes; 
Table 1. Details of diabetic patients at the start of the study

\begin{tabular}{|c|c|c|}
\hline & $\begin{array}{l}\text { Sorbinil group } \\
(n=14)\end{array}$ & $\begin{array}{l}\text { Placebo group } \\
(n=14)\end{array}$ \\
\hline$F: M$ & $6: 8$ & $6: 8$ \\
\hline Age (years) & $54.1 \pm 9.1(31-64)$ & $50.2 \pm 11.3(20-63)$ \\
\hline $\begin{array}{l}\text { Duration of diabetes } \\
\text { (years) }\end{array}$ & $23.1 \pm 12.5(3-42)$ & $14.9 \pm 11.8(1-38)$ \\
\hline $\begin{array}{l}\text { Treatment: } \\
\text { oral } \\
\text { diet } \\
\text { insulin }\end{array}$ & $\begin{array}{r}2 \\
- \\
12\end{array}$ & $\begin{array}{r}1 \\
2 \\
11\end{array}$ \\
\hline Insulin dose (IU/day) & $45.7 \pm 19.7(12-82)$ & $44.0 \pm 18.9(20-88)$ \\
\hline $\mathrm{HbA}_{1}(\%)$ & $10.3 \pm 2.6(6.2-16.3)$ & $10.2 \pm 1.8(7.7-12.9)$ \\
\hline $\begin{array}{l}\text { Plasma creatinine } \\
(\mu \mathrm{mol} / \mathrm{l})\end{array}$ & $86.0 \pm 19.1(53-118)$ & $94.9 \pm 26.8(67-179)$ \\
\hline $\begin{array}{l}\text { Proteinuria } \\
(>500 \mathrm{mg} / \text { day })\end{array}$ & 2 & 6 \\
\hline $\begin{array}{l}\text { Neuropathy: } \\
\text { peripheral } \\
\text { peripheral+ } \\
\text { autonomic }\end{array}$ & $\begin{array}{r}4 \\
10\end{array}$ & $\begin{array}{l}6 \\
8\end{array}$ \\
\hline $\begin{array}{l}\text { Retinopathy: } \\
\text { background } \\
\text { proliferative }\end{array}$ & $\begin{array}{l}5 \\
1\end{array}$ & $\begin{array}{l}3 \\
3\end{array}$ \\
\hline
\end{tabular}

Results expressed as mean $\pm \mathrm{SD}$ with range in parentheses
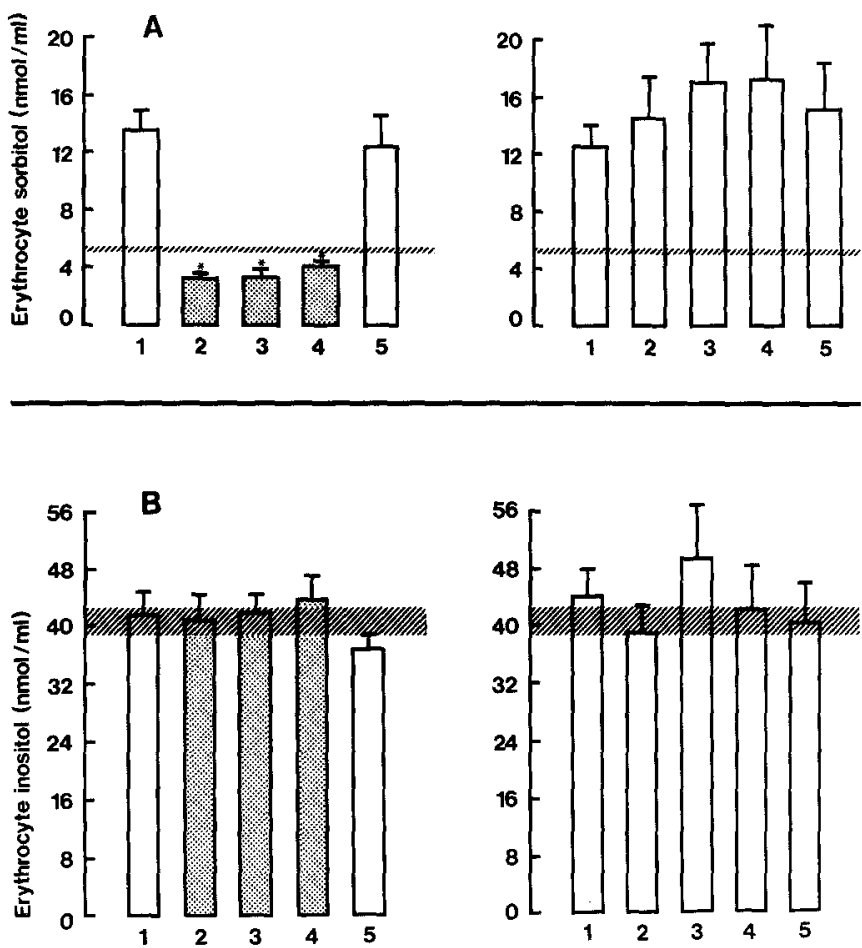

Fig. 1. A Erythrocyte sorbitol and B myo-inositol concentrations (mean $\pm \mathrm{SEM}$ ) in diabetic patients during the sorbinil study. Lefthand panels represent the sorbinil group; the right-hand panels the placebo group. 1: after a run-in period of 4 weeks of placebo; $2,3,4$ : after $4,8,12$ weeks of sorbinil (shaded bars) or placebo (open bars); 5 : after a washout period of 4 weeks of placebo. * $p<0.001$ compared with placebo (paired t-test). The cross-hatched area represents the non-diabetic normal range (mean $\pm S E M)$
$1 \mathrm{nmol} / \mathrm{ml}$ erythrocytes corresponds to approximately $3 \mathrm{nmol} / \mathrm{g}$ haemoglobin. The recovery of myo-inositol and sorbitol from erythrocytes was $99 \pm 4.1 \%$ and $101 \pm 3.2 \%$, respectively (mean $\pm \mathrm{SD}, n=6$ ). Reproducibility, expressed as coefficient of variation interassay, was $6.1 \%$ and $4.0 \%$ for myo-inositol and sorbitol, respectively. $\mathrm{HbA}_{1}$ was assayed by a microcolumn method [14], plasma sorbinil by high performance liquid chromatography [15]. Except where otherwise stated, results are mean $\pm S E M$. For statistical analyses Student's t-tests, paired and unpaired, were used.

\section{Results}

Sorbitol and myo-inositol levels in erythrocytes from diabetic patients during placebo or sorbinil treatment are shown in Figure 1. The mean $\mathrm{HbA}_{1}$ in the sorbinil group during placebo was $10.3 \pm 0.4 \%$ and during sorbinil $10.2 \pm 0.4 \%$. In the placebo group, $\mathrm{HbA}_{1}$ was $10.6 \pm$ $0.2 \%$. The mean plasma sorbinil level during treatment with $200 \mathrm{mg}$ sorbinil daily was $6.4 \pm 0.6 \mu \mathrm{g} / \mathrm{ml}$.

The mean erythrocyte sorbitol level in diabetic patients was significantly higher than in control subjects $(13.1 \pm 0.9$ and $5.2 \pm 0.3 \mathrm{nmol} / \mathrm{ml}$ erythrocytes, respectively, $p<0.001$ ). Treatment with $200 \mathrm{mg}$ sorbinil daily reduced the erythrocyte sorbitol values to normal (period 4) or slightly below normal (period 2: $p<0.001$; period 3: $p<0.01$ ). The mean erythrocyte myo-inositol concentration in diabetic patients was similar to that in control subjects $(43.2 \pm 2.9$ and $40.5 \pm 1.9 \mathrm{nmol} / \mathrm{ml}$ erythrocytes, respectively). The range in erythrocyte myo-inositol concentrations in diabetic patients was larger than in control subjects (19-131 and $29-58 \mathrm{nmol} /$ $\mathrm{ml}$ erythrocytes, respectively) due to high values in erythrocytes from two patients $(95$ and $131 \mathrm{nmol} / \mathrm{ml}$ erythrocytes). These patients showed marked proteinuria and elevated plasma creatinine levels ( $>$ $150 \mu \mathrm{mol} / \mathrm{l}$ ). Sorbinil treatment of diabetic patients did not change erythrocyte myo-inositol levels.

\section{Discussion}

The treatment of diabetic patients with $200 \mathrm{mg}$ sorbinil daily for 4 weeks reduced erythrocyte sorbitol concentrations by $75 \%$, resulting in values slightly below normal. This reduction is greater than that found by Malone et al. [12] after treatment of Type 1 diabetic patients with a daily dose of $250 \mathrm{mg}$ sorbinil (52\%). This difference can probably be explained by the methods used to determine erythrocyte sorbitol. The specificity of the sorbitol dehydrogenase method, as used by Malone et al, depends on the specificity of the commercially available enzyme preparation $[13,16]$. Especially when erythrocyte sorbitol levels are low, as can be expected after sorbinil treatment, the contribution of non-specific components can be relatively high.

Measurement of both sorbitol and myo-inositol in nerve tissue after induction of experimental diabetes and during treatment has given information about the metabolic abnormalities associated with reduced nerve 
conduction velocity $[6,7]$. In clinical studies more accessible tissues have to be chosen to monitor the possible biochemical effects of dietary myo-inositol or sorbinil treatment. Recently Gregersen et al. [17] investigated the effect of oral supplementation of myo-inositol on its concentration in human plasma, erythrocytes, urine and muscle tissue in four diabetic and four control subjects. They found no indication of a lack of myo-inositol in blood or tissue from diabetic patients. The dietary myoinositol supplement did increase plasma and erythrocyte myo-inositol, in the diabetic patients even more than in control subjects, but did not affect impaired nerve conduction velocity.

In the present study, no difference was found between the mean myo-inositol content of erythrocytes from diabetic and control subjects. The range of erythrocyte myo-inositol in the diabetic patients, however, was larger than in control subjects, due to high values in erythrocytes from two insulin-dependent patients, who showed marked proteinuria and elevated plasma creatinine values. The erythrocyte myo-inositol levels probably reflect plasma myo-inositol concentrations, as was shown by Gregersen et al. [17] and by Dawson and Freinkel [18]. A supranormal rise in plasma myo-inositol concentration after a meal or an oral myo-inositol load have been demonstrated by Clements and Reynertson [19] in newly-diagnosed untreated diabetic patients. This myo-inositol intolerance was, however, restored to normal by insulin therapy. In insulin-treated diabetic patients, increased fasting plasma myo-inositol concentrations have been found only in those patients who had impaired renal function $[19,20]$. The high myoinositol levels which we found in erythrocytes from some diabetic patients might therefore be explained by their impaired renal function.

Sorbinil treatment did not affect erythrocyte myoinositol content, despite restoration of intracellular sorbitol levels to normal. The effect of sorbinil treatment on myo-inositol concentrations in nerve tissue from diabetic patients is still unknown. From our data we conclude that a possible effect of sorbinil on nerve myo-inositol levels will not be reflected in erythrocyte myo-inositol concentrations. The effect of sorbinil on intracellular sorbitol concentrations can, however, be monitored by measuring erythrocyte sorbitol concentrations.

Acknowledgments. We thank Pfizer, Sandwich, Kent, UK, for financial support and supplies of sorbinil. The technical assistance of Ms. B. Geenen is gratefully acknowledged.

\section{References}

1. Winegrad AI, Simmons DA, Martin DB (1983) Has one diabetic complication been explained? N Engl J Med 308: 152-154

2. Clements Jr RS (1979) Diabetic neuropathy - new concepts of its etiology. Diabetes 28: 604-611

3. Winegrad AI, Greene DA (1976) Diabetic polyneuropathy: the inportance of insulin deficiency, hyperglycemia and alterations in myo-inositol metabolism in its pathogenesis. N Engl J Med 295: 1416-1421

4. Mayer JH, Tomlinson DR (1983) Prevention of defects of axonal transport and nerve conduction velocity by oral administration of myo-inositol or an aldose reductase inhibitor in streptozotocin diabetic rats. Diabetologia 25: 433-438

5. Greene DA, De Jesus Jr. PV, Winegrad AI (1975) Effects of insulin and dietary myo-inositol on impaired peripheral motor nerve conduction velocity in acute streptozotocin diabetes. J Clin Invest 55: 1326-1336

6. Gillon KRW, Hawthorne JN, Tomlinson DR (1983) Myo-inositol and sorbitol metabolism in relation to peripheral nerve function in experimental diabetes in the rat: the effect of aldose reductase inhibition. Diabetologia 25:365-371

7. Finegold D, Lattimer SA, Nolle S, Bernstein M, Greene DA (1983) Polyol pathway activity and myo-inositol metabolism. A suggested relationship in the pathogenesis of diabetic neuropathy. Diabetes 32: 988-992

8. Servo C, Palo J, Pitkänen E (1977) Polyols in the cerebrospinal fluid and plasma of neurological, diabetic and uremic patients. Acta Neurol Scandinav 56: 111-116

9. Servo C (1980) Sorbitol and myoinositol levels in the cerebrospinal fluid of diabetic patients. Acta Endocrinol (94 Suppl) 328: 133-137

10. Mayhew JA, Gillon KRW, Hawthorne JN (1983) Free and lipid inositol, sorbitol and sugars in sciatic nerve obtained post-mortem from diabetic patients and control subjects. Diabetologia 24: 13-15

11. Malone JI, Knox G, Benford S, Tedesco TA (1980) Red cell sorbitol. An indicator of diabetic control. Diabetes 29:861-864

12. Malone JI, Leavengood H, Peterson MJ, O'Brien MM, Page G, Aldinger CE (1984) Red blood cell sorbitol as an indicator of polyol pathway activity. Inhibition by sorbinil in insulin-dependent diabetic subjects. Diabetes 33: 45-49

13. Popp-Snijders C, Lomecky MZ, Jong AP de (1983) Determination of sorbitol in erythrocytes of diabetic and healthy subjects by capillary gas chromatography. Clin Chim Acta 132: 83-89

14. Gabbay KH, Hasty K, Breslow JL, Ellison RC, Bunn HF, Gallop PM (1977) Glycosylated haemoglobins and long-term blood glucose control in diabetes mellitus. J Clin Endocrinol Metab 44: $859-864$

15. Foulds G, O'Brien MM, Bianchine JR, Gabbay KH (1981) Kinetics of an orally absorbed aldose reductase inhibitor, sorbinil. Clin Pharmacol Ther 30: 693-700

16. Gabbay KH (1973) The sorbitol pathway and the complications of diabetes. N Engl J Med 288: 831-836

17. Gregersen $G$, Bertelsen B, Harbo $H$, Larsen E, Andersen JR, Helles A, Schmiegelow M, Christensen JEJ (1983) Oral supplementation of myoinositol: effects on peripheral nerve function in human diabetics and on the concentration in plasma, erythrocytes, urine and muscle tissue in human diabetics and normals. Acta Neurol Scand 67: 164-172

18. Dawson RMC, Freinkel N (1961) The distribution of free mesoinositol in mammalian tissues, including some observations on the lactating rat. Biochem J 78: 606-610

19. Clements Jr. RS, Reynertson R (1977) Myo-inositol metabolism in diabetes mellitus. Effect of insulin treatment. Diabetes 26: 215-221

20. Servo C (1977) Accumulation of myo-inositol in plasma and red cells of diabetic patients. Acta Med Scand 201: 59-62

Received: 23 March 1984

and in revised form: 31 August 1984

Dr. C. Popp-Snijders

Department of Endocrinology

Free University Hospital

De Boelelaan 1117

1007 MB Amsterdam

The Netherlands 